\author{
Katarzyna Jasikowska \\ Uniwersytet Jagielloński
}

\title{
ETYCZNE DYLEMATY PRACY KOBIET W DOBIE GLOBALIZACJI - POLSKIE WĄTKI ${ }^{1}$
}

\section{Płeć społeczno-kulturowa a globalizacja}

Wpływ globalnych trendów gospodarczych na życie ludzi jest różny w zależności od płci kategorii osób którą rozpatrujemy. Globalizacja gospodarcza inaczej wpływa na życie kobiet aniżeli na życie mężczyzn zwłaszcza w sferze rynku pracy i zatrudnienia. Ocena współczesnej fazy globalizacji dla sytuacji kobiet na świecie nie jest oczywiście jednoznaczna. $Z$ jednej strony przyśpieszony rozwój gospodarczy w wielu regionach świata daje kobietom bezprecedensową okazję wejścia na rynek pracy i zdobycia dzięki zarobionym w ten sposób pieniądzom pewnej dozy ekonomicznej niezależności. Z drugiej jednak strony, kobiety, w porównaniu z mężczyznami, są nadal ,niewidzialne” zarówno w sferze biznesu jak i aktywności politycznej [Samouiller i Jare: 2007]. Co więcej, istniejące dysproporcje w zakresie posiadanej własności, władzy, prestiżu i wykształcenia utrzymują się bądź pogłębiają. Przykładowo kobiety posiadają zaledwie $1 \%$ własności w skali świata oraz zarabiają $10 \%$ światowych dochodów [Human Development Report: 1995], a w 2005 r. kobiety stanowiły 16\% wszystkich parlamentarzystów na świecie [Samouiller i Jare: 2007: 519].

Kluczem do zrozumienia sytuacji kobiet we współczesnej gospodarce jest pojęcie płci społeczno-kulturowej (ang. gender) i dyskryminacji jako efektu przypisywania takiej a nie innej pozycji społecznej ze względu na płeć. Płeć jest obiektywnym faktem biologicznym. Pierwszorzędowe i drugorzędowe cechy płciowe pozwalają nam jednoznacznie określić płeć danej osoby. Z socjologicznego punktu widzenia nie mniej ważne jest, iż ów obiektywny fakt biologiczny podlega w każdej społeczności interpretacji kulturowej. W każdej społeczności

${ }^{1}$ Tekst stanowi rozbudowaną wersję artykułu pt. Praca kobiet $w$ dobie globalizacji $-w y$ brane watki, złożony do pracy zbiorowej pod red. Anny Senyszyn pt. Wyzwania wspótczesnej Europy. Równouprawnienie kobiet. 
funkcjonują wyobrażenia na temat „kobiecości” i „męskości” wraz z precyzyjnie określonymi normami zachowania, postępowania, myślenia a nawet wyglądu zewnętrznego uważanego za właściwy w odniesieniu do każdej z płci. W kulturze zachodniej za cechy „typowo męskie” uznaje się np. agresję, chęć dominacji, zdolności przywódcze, a za cechy „typowo kobiece” zależność, estetyczną wrażliwość czy wylewność emocjonalną. Nie w każdym społeczeństwie te same czynności uważane są za męskie i kobiece. Najczęściej mężczyźni wykonują prace wymagające siły fizycznej, a kobiety te, które można wykonywać przy mniejszym wysiłku fizycznym i w pobliżu domu. Niezależnie od tego, jakie są to czynności, te, które uznawane są za męskie, traktowane są jako ważniejsze niż te, które uznawane są za kobiece [Szacka: 2003: 350]. Stąd, obiektywna różnica biologiczna podlega kulturowej definicji i staje się wyznacznikiem nierówności społecznej. Nierówności społeczne związane z różnicami płci nie są szczególną cechą np. społeczeństw słabo rozwiniętych, ale uwidaczniają się wszędzie bez względu na rozprzestrzeniający się w społeczeństwach tzw. Zachodu ideał merytokracji czy prawa człowieka.

\section{Kobiety i rozwój społeczny - WID, WAD i GAD}

Żyjemy w czasach powracających globalnych kryzysów. Niekorzystne warunki wymiany pomiędzy bogatymi a biednymi krajami, rosnące zadłużenie tych ostatnich, nieudane $w$ wielu regionach programy restrukturyzacyjne odbijają się niekorzystnie zwłaszcza na sytuacji kobiet. Wiele biednych krajów, w zamian za przyznawane przez Międzynarodowy Fundusz Walutowy pożyczki, wdraża programy restrukturyzacyjne (structural adjustment programmes - SAP) polegające $\mathrm{m}$. in. na deregulacji finansowej, tworzeniu stref produkcji na eksport, redukcji zakresu opieki społecznej państwa, włączając w to np. dotowanie żywności. Kobiety nie są na ogół beneficjentami programów restrukturyzacyjnych. W krajach Trzeciego Świata kobiety są producentkami 70\% żywności otrzymując 5\% dostępnych dla rolnictwa pożyczek [Dickensom: 1997: 100]. Restrukturyzacja gospodarki oznacza wycofywanie się państwa i przesuwanie szeregu wydatków ze sfery publicznej do prywatnej. Usługi, za które jeszcze do niedawna częściowo lub w całości płaciło państwo stają się w coraz większej mierze „prywatną sprawa" obywateli. Sektory takie jak opieka zdrowotna, edukacja, opieka nad osobami w podeszłym wieku, ubezpieczenia społeczne, czy więziennictwo w coraz większym stopniu prywatyzują się. Zmiany te zmieniają życie milionów ludzi na całym świecie. Niekorzystne efekty owych zmian dotyczą przede wszystkim kobiet.

Po pierwsze, jeżeli państwo wycofuje się z pełnienia pewnych funkcji związanych z opieka zdrowotna, edukacją, czy opieką społeczną to zwolnienia $\mathrm{w}$ tych sektorach gospodarki dotyczą przede wszystkim kobiet (pink collar wor- 
kers). Redukcja etatów w sprywatyzowanych niegdysiejszych sektorach państwowych w głównej mierze dotyczy kobiet, które wcześniej zdominowały owe sektory. Państwa Europu Środkowo-Wschodniej, w tym Polski, są tego doskonałym przykładem.

Po drugie, jeżeli państwo wycofuje się z różnych form pomocy gospodarstwom domowym, kobiety w wielu społeczeństwach, jako tradycyjnie odpowiedzialne za prowadzenie domu, opiekę nad dziećmi, chorymi, czy starszymi osobami, muszą ów niedobór jakoś nadrobić zwiększonymi nakładami własnej pracy. To oznacza mniej czasu i sił na realizowanie innych planów i zadań (np. edukacje własną, czy prace zarobkową, aktywność polityczną czy obywatelska).

Po trzecie, społeczne koszty globalizacji gospodarczej odbijają się niekorzystnie na sytuacji kobiet - mówimy wręcz o feminizacji ubóstwa. Jeżeli globalizacja w sferze gospodarczej oznacza oddalanie się bieguna nędzy i bogactwa zarówno w wymiarze międzynarodowym, jak i w obrębie poszczególnych państw, obszar nędzy zajmują przede wszystkim kobiety. Aż 70\% spośród 1,3 miliarda osób żyjących za mniej niż 1 USD dziennie stanowią kobiety [Human Development Report: 1999].

Perspektywa z jakiej analizuje się miejsce kobiet w rozwoju społecznym zmienia się w czasie. Od lat 50 . do początku lat 70 . obowiązywała perspektywa teoretyczna określana mianem „Kobiety w Rozwoju” (Women In Development WID). WID nawiązywała w swej wymowie do teorii modernizacji, zakładajacych błędnie, iż kobiety pozostają wyłączone poza obszar gospodarki produkcyjnej. Inaczej mówiąc, rozwój odbywał się bez udziału kobiet zajętych ,,pracami domowymi" i wychowywaniem dzieci. Co więcej, zwolenniczki WID uważały, iż kobiety powinny zostać włączone do gospodarki poprzez legalistyczne i administracyjne działania.

W drugiej połowie lat 70. powstała perspektywa określana mianem „Kobiety i Rozwój" (Women And Development - WAD). Bezpośredni impuls do ich powstania dostarczyły teorie zależności. Okazało się, że kobiety zawsze miały znaczący wkład w rozwój. Argumentowano, iż praca kobiet w prywatnym i publicznym sektorze zawsze stanowiła centralną część procesów gospodarczych. Kobiety stanowią tzw. „niewidzialną siłę roboczą”, której efekty działań nie są w prosty sposób mierzone i przeliczane na odpowiednie waluty (tak jak to ma miejsce w przypadku pracy zarobkowej na rynku pracy). To na co należało więc zwrócić szczególna uwagę to zasady na jakich kobiety są włączane w proces rozwoju.

Dopiero lata 80. wiążą się z pewnym novum w zakresie pojmowania roli kobiet w rozwoju. Płeć społeczno-kulturowa i rozwój (Gender and Development - GAD), to perspektywa traktująca wszystkie aspekty aktywności kobiet jako jedną powiązaną całość (funkcje rozrodcze, praca niezarobkowa i zarobkowa). GAD kwestionuje istniejące w każdym społeczeństwie przypisywanie ról społecznych ze względu na płeć społeczno-kulturową. Kobiety opiekują się dzieć- 
mi, wykonują prace płatne i nieodpłatne i trudno te sfery całkowicie od siebie oddzielić.

\section{Etyczne dylematy pracy kobiet $\mathrm{w}$ dobie globalizacji}

W nomenklaturze przyjętej przez Organizację Narodów Zjednoczonych elementem politycznej poprawności jest mówienie o ,pracy płatnej” i ,pracy nieodpłatnej" kobiet. W tym ostatnim przypadku chodzi o zajmowanie się domem i rodziną. Używając kreślenia „nieodpłatna praca” (ang. unpaid work) nadajemy temu zjawisku wymiar polityczny podkreślając, że to jest praca i to taka, za którą kobiety nie otrzymują wynagrodzenia. Tak więc niekwestionowany do 2008 r. neoliberalny paradygmat zakładający liberalizację rynku we wszystkich sferach życia pomijał te sfery aktywności, które, bez względu na obszar cywilizacyjny, pozostają domeną kobiet: $70 \%$ pracy wykonywanej na naszej planecie to praca nieodptatna: wszelki rodzaj sprawowania opieki, wychowywanie dzieci $i$ zajmowanie sie ich edukacja, praca $w$ gospodarstwie domowym, ogrodzie $i$ w polu (...) Jedynie jedna trzecia pracy wykonywanej przez kobiety jest wynagradzana pieniężnie; pozostałe dwie trzeciego to praca nieodpłatna wymykajaca się ekonomicznym statystykom. W przypadku mężczyzn proporcje te sa niemal idealnie odwrócone [Wichterich: 2000: 97].

Organizacja Narodów Zjednoczonych posługuje się w swoich raportach jeszcze jednym istotnym terminem diagnozując sytuację kobiet w dobie globalizacji. Tym terminem jest praca polegająca na świadczeniu opieki (ang. care, caring labour). Chodzi tutaj o opiekę nad dziećmi, chorymi, czy osobami w podeszłym wieku, której dostarczycielkami są, jak już zostało wcześniej powiedziane, w przeważającej mierze właśnie kobiety. Opieka oznacza tutaj emocjonalne zaangażowanie, osobiste kontakty face-to-face, nawet jeżeli sprawowanie opieki powodowane jest w głównej mierze poczuciem obowiązku wynikającym z przyjętych w danej społeczności norm społecznych. Według ONZ, rozwój społeczny jest możliwy nie tylko dzięki wzrastającym dochodom ludności, lepszemu wykształceniu, lepszej opiece zdrowotnej, poszerzaniu praw wyborczych czy dbałości o środowiska, ale także dzięki możliwości świadczenia opieki w stosunku do wszystkich potrzebujących. Innymi słowy, zrównoważony rozwój nie jest możliwy, jeżeli ludzie na każdym etapie swojego życia nie będą otrzymywali opieki i emocjonalnego wsparcia.

Niepokój budzi fakt, iż globalizacja gospodarcza ogranicza zarówno chęci jak i możliwości kobiet w świadczeniu opieki. Po pierwsze, globalne rynki nie nagradzają postaw altruistycznych i chęci pomagania innym. Dominuje logika osiągania jak największego zysku kosztem każdej dziedziny życia. Powstaje więc problem, czy kobiety będą chciały kontynuować tradycyjnie przypisane im role opiekuńcze w swoich społecznościach. 
Po drugie, wchodzenie kobiet na rynek pracy w wielu regionach świata powoduje, iż kobiety mają nie tylko inne horyzonty poznawcze ale także najzwyczajniej znacznie mniej czasu na opiekowanie się potrzebującymi członkami rodziny bliższej i dalszej.

Po trzecie, wycofywanie się państwa z wielu dziedzin życia (ograniczenia wydatków publicznych) przy równoczesnym wychodzeniu kobiet z tradycyjnie przypisanych im ról (np. opiekunek) prowadzi do zwiększania społecznych kosztów transformacji społeczno-gospodarczych i rozwoju w wielu regionach świata. Przykładowo spodziewana długość życia w siedmiu spośród krajów Europy Wschodniej i Wspólnoty Niepodległych Państw była niższa w 1995 r. od tej z 1987 r. aż o pięć lat [Human Development Report: 1999: 79]

Współczesne przemiany dotyczące produkcji i rynku pracy w międzynarodowej skali są niekorzystne dla kobiet, zwłaszcza pochodzących z tzw. Trzeciego Świata. Delokalizacja produkcji polegająca na sytuowaniu zakładów produkcyjnych w najkorzystniejszym dla akcjonariuszy położeniu geograficznym, sprzyja przenoszeniu tzw. „,brudnych technologii” do krajów najuboższych. Z punktu widzenia producentów określonych towarów nie warto borykać się z koniecznością przestrzegania przepisów dotyczących ochrony środowiska naturalnego, praw pracowniczych, czy konieczności płacenia wysokich podatków, jeśli można przenieść produkcję do wielu regionów świata pozbywając się części bądź wszystkich powyższych problemów. Produkcja przenoszona jest do krajów, które oferują najkorzystniejsze warunki, nie tylko w kwestiach standardów ochrony środowiska, płacenia podatków, ale również oferują tanią, głównie kobieca, siłę roboczą. Proces ten widoczny jest zwłaszcza w przemyśle tekstylno-odzieżowym, obuwniczym, elektronicznym, czy w produkcji zabawek.

Proces ten określa się mianem feminizacji najemnej siły roboczej lub feminizacją proletariatu. Kobiety zatrudniane są w najmniej nowoczesnych sektorach gospodarki, gdzie wykonuje się najbardziej pracochłonne i najgorzej płatne zajęcia. Na przykład odsetek kobiet wśród pracowników pracujących w domu na zlecenie lub chałupniczo wynosił odpowiednio: w Chile 82\% (w 1997 r.), na Filipinach 79\% (lata 1993-95), w Tajlandii 80\% (w 1999 r.), w Brazylii 79\% (w 1995 r.), w Gwatemali 77\% (w 2000 r.), w Indiach 44\% (w latach 19992000), w Meksyku 43\% (w 1995 r.), w Wenezueli 63\% (w 1997 r.) [ILO: 2002: 47]. Praca taka w niewielkim stopniu lub w ogóle nie podlega jakiejkolwiek ochronie ze strony państwa czy związków zawodowych. W przypadku braku wypłat, bądź kwestionowania jakości dostarczonego przez pracownice towaru są one pozostawione same sobie.

Kobiety stanowią główna siłę najemną w tzw. sweatshops, będących nowoczesnym odpowiednikiem niewolniczej pracy. Wiele znanych korporacji transnarodowych (KTN-y) najchętniej zatrudnia młode kobiety (do 25 roku życia), gdyż są tańszymi i bardziej zdyscyplinowanymi pracownikami od mężczyzn. Kobiety o wiele rzadziej buntują się przeciwko standardom pracy obowiązują- 
cym w danym zakładzie, pracują bez narzekania nawet w najgorszych warunkach [Frobel, Heinrich, Kreye: 2000: 257].

Proces kumulowania się najnowocześniejszych technologii zarezerwowany jest wyłącznie dla krajów tzw. Triady. Oznacza to, że w najbogatszych krajach świata nakłady na współpracę biznesu z gospodarką pozwalają im utrzymać rolę liderów w dziedzinie produkcji wysoko przetworzonych towarów oraz usług. Kraje, które nie inwestują w rozwój nauki i najnowocześniejszych technologii pozostają coraz bardziej w tyle. Ich konkurencyjność na arenie międzynarodowej spada. Proces ten wykazuje tendencje do pogłębiania się.

Jak wykazała w swoich pracach Saskia Sassen [2000; 2007], współczesną fazę kapitalizmu charakteryzuje szereg komplementarnych procesów; delokalizacja produkcji i wynikający z niej wzrost produkcji na eksport w krajach Trzeciego Świata; migracje młodych kobiet w biednych krajach do nowych sfer przemysłowych i emigracja do krajów wysoko rozwiniętych. Kraje Trzeciego Świata przyjmują kolejnych inwestorów zagranicznych dzięki którym uzyskują dostęp do światowych rynków (jedyny rodzaj dostępu na jaki mogą sobie pozwolić). W rezultacie w wielu krajach powstają specjalne obszary przemysłowe, tzw. Export Processing Zones, do których migrują zwłaszcza młode kobiety, w poszukiwaniu pracy. Liczba miejsc pracy w danym kraju zwiększa się. Warto dodać, iż ze względu na ciężkie warunki pracy, tempo rotacji pracowników w tego typu zakładach jest bardzo duże. Przykładem mogą być chociażby Shenzen w Chinach, w którym liczba zarejestrowanych pracowników wzrosła z 30000 w 1980 r. do 3 milionów w 2000 r. Warto dodać, iż 70\% pracowników to kobiety poniżej 25 roku życia, migrantki z terenów rolniczych, posiadające prawo tymczasowego pobytu bez zameldowania i pozbawione tym samym praw obywatelskich w Shenzen ${ }^{2}$. Innym przykładem może być maquiladoras rozciągające się w Meksyku wzdłuż granicy z USA. Warto dodać, iż po wejściu w życie NFTA w 1993 r. liczba Meksykanów żyjących w ubóstwie zwiększył się o osiem milionów.

Spośród byłych pracowników zakładów ze specjalnych obszarów przemysłowych rekrutują się również emigranci do krajów wysokouprzemysłowionych (np. do USA). Poprzez doświadczenia pracy dla zagranicznych koncernów oraz doświadczenia pozostawania $\mathrm{w}$ długotrwałej rozłące $\mathrm{z}$ rodziną część pracownic z EPZ decyduje się na emigracje zarobkowa za granicę [Sassem: 2000; 2007]. Sytuacja ta dotyczy także krajów takich jak Meksyk czy Kolumbia, w których rozwija się rynek wewnętrzny (tzn. nie wszystkie towary produkowane są wyłącznie na eksport).

Można więc powiedzieć, że migracje młodych kobiet do nowych sfer przemysłowych związane są z przekształceniami gospodarczymi w gospodarce świa-

\footnotetext{
${ }^{2}$ Informacje dostępne na stronie Women Working Worldwide.
} 
towej - jest to m. in. efekt delokalizacji produkcji. Korporacje zakładające nowe zakłady pracy w różnych regionach świata potrzebują taniej siły roboczej.

W krajach w których rozwijają się branże zaawansowanych technologii (Pierwszy Świat) potrzeba coraz to większej liczby niskopłatnych miejsc pracy w sektorze produkcji (w krajach Trzeciego Świata) oraz obsłudze scentralizowanej obsługi i aparatu zarządzającego na miejscu (w Pierwszym Świecie). Innymi słowy, w siedzibach wielkich korporacji i firm potrzebne są miliony etatów dla sprzątaczek, kucharek, pracowników obsługi technicznej, dostawców, fryzjerów, śmieciarzy oraz szeregu innych pracowników (w tym wielu legalnych i nielegalnych emigrantów) bez których nastąpiłby paraliż wielkich światowych metropolii.

Przeobrażenia w strukturze zatrudnienia w krajach Pierwszego i Trzeciego Świata można uznać za komplementarne. O ile w krajach bogatych rośnie zatrudnienie w szeroko rozumianych usługach, o tyle w krajach najuboższych rośnie zatrudnienie w przemyśle (dotyczy to zwłaszcza kobiet) i spada zatrudnienie w usługach. Sa to dwa wzajemnie ze sobą powiązane procesy. W gospodarkach opierających się w głównej mierze na usługach (obok zapotrzebowania na specjalistów najwyższej klasy) wzrasta równocześnie zapotrzebowanie na niskopłatną pracę.

\section{Praca kobiet w Polsce w dobie globalizacji - wybrane wątki}

Pozostaje fundamentalne pytanie czy globalne trendy dotyczące kobiet globalnego Południa mają swoje odpowiedniki w Polsce? Po przystapieniu do Unii Europejskiej Polska została symbolicznie włączona do krajów tzw. globalnej Północy. Akcesja nie stanowi jednak gwarancji zrównoważonego rozwoju, w którym wszystkie kategorie osób czerpią w porównywalnym stopniu korzyści $\mathrm{z}$ transformacji. Transformacja ma zupełnie inny wpływ na kobiety niż na mężczyzn. W badaniu, czy transformacja polepszyła sytuacje kobiet, prawdziwym testem jest to, czy uczyniła je bardziej wolnymi, czy bardziej skrepowanymi niż wcześniej. Jak dotad $w$ wielu krajach przechodzacych transformacje prawdziwa zdaje się być ta druga odpowiedź [Word Bank: 1996: 72]. Pomimo faktu, że Polki obecne były na rynku pracy poprzez cały okres komunizmu w proporcjach znacznie przewyższających kraje starej Unii Europejskiej ${ }^{3}$, przemiany gospodarcze ostatnich dwudziestu lat nie uczyniły ich beneficjentkami transformacji. Oto lista argumentów na rzecz powyższej tezy wymienianych w rozlicznych pracach na ten temat: 1) współczynnik aktywności zawodowej kobiet sukcesywnie maleje; 2) kobiety są pierwsze w kolejce do zwolnienia przy ogólnej akceptacji ta-

${ }^{3}$ CEE Participation Rates from EC, 1992, s. 35; EC Participation Rates from Eurostat, 1991, s. 44-45. 
kiego stanu rzeczy; 3) kobiety stanowią większość osób z najniższą pensją; 4) stopa bezrobocia kobiet przewyższa ten sam wskaźnik dla mężczyzn; 5) kobiety stanowią większość długotrwale bezrobotnych; 6) nawet wykształcenie chroni kobiety przed bezrobociem w mniejszym stopniu aniżeli w odniesieniu do mężczyzn; 7) kobiety w Polsce pracują na drugorzędnym rynku pracy kierującym się innymi aniżeli męski rynek pracy regułami; 8) kobiety zarabiaja w Polsce od 20 do 30\% mniej aniżeli mężczyźni zatrudnieni na podobnych posadach; 9) kobiety wolniej awansują bądź zatrzymują się na pewnym poziomie w hierarchii zakładu pracy (zjawisko tzw. ,szklanego sufitu” i ,lepkiej podłogi”); 10) praca kobiet jest częściej traktowana jako „dorabianie do domowego budżetu" aniżeli autonomiczna kariera; 11) rezultatem takiego stanu rzeczy są np. mniejsze oczekiwania płacowe kobiet w porównaniu do mężczyzn oraz rzadsze nastawienie na rozwijanie zawodowej kariery jako ścieżki samorealizacji odpowiedniej dla kobiety; 12) niższe świadczenia emerytalne (średnio o 30\%). Ogólnie rzecz biorąc, ukute przez Henryka Domańskiego na początku lat dziewięćdziesiątych określenie „,zadowolony niewolnik” wydaje się nadal sugestywnie oddawać sytuację kobiet w Polsce - dzielących swój czas pomiędzy odpłatną i nieodpłatną pracę bez narzekań.

Zakładając, że sytuacja zawodowa jest podstawowym wyznacznikiem pozycji społecznej w nowoczesnych społeczeństwach można powiedzieć, iż Polki (...) przegrywajac na rynku pracy przegrywaja z kretesem na wszystkich polach aktywności społecznej (...) wykluczanie kobiet ze sfer aktywności zawodowej wpisuje sie w szerszy trend - wykluczenie ze sfery publicznej [Desperak: 2004: 4-9]. Doskonałą ilustracją takiego stanu rzeczy jest cała batalia wokół tzw. ustawy antyaborcyjnej. W analizie całego dyskursu na ten temat uderza dominujące stanowisko, reprezentowane także przez zwolenników legalizacji aborcji, iż kobiety to pasywne i godne pożałowania ofiary wadliwego ustawodawstwa. Autonomiczne decydowanie o sobie nie mieści się w takiej argumentacji. Aborcja jest $\mathrm{w}$ polskiej debacie, nie wliczając $\mathrm{w}$ to marginalizowanych środowisk feministycznych, definiowana jako zło moralne a wynikające z takiego przekonania rygorystyczne prawo utwierdza patriarchalny porządek [Graff: 2001; 2008, Nowicka: 2009]. Zakaz aborcji w Polsce jest wyrazem ideologicznej hegemonii katolicyzmu, świadectwem męskiego szowinizmu, pogardy i okrucieństwa wobec warstw niższych społecznie, autorytarnej kultury sprawowania wtadzy, pasywności i braku spotecznej solidarności, wreszcie zwyktego zakłamania [Kozłowski: 2009: 2].

Poza najbardziej widoczną batalią dotyczącą bezpośrednio kobiet, czyli kwestią prawa antyaborcyjnego, w Polsce toczy się jeszcze jedna, tym razem „cicha rewolucja”. Podobnie jak ma to miejsce w krajach Trzeciego Świata, także w Polsce kobiety w znacznie większym stopniu aniżeli mężczyźni zostają obciążone kosztami restrukturyzacji w kierunku gospodarki rynkowej. Jak wykazały badania z 2002 r. w Polsce mężczyźni tygodniowo spędzają w pracy 
średnio o dziewięć godzin i dwadzieścia siedem minut więcej niż kobiety, ale w skali tygodnia kobiety poświęcają na prace domowe i opiekę nad dziećmi o 45 godzin więcej [Titkow, Duch-Krzystoszek, Budrowska: 2002]. Warto dodać, iż wartość pracy domowej jest porównywalna $\mathrm{z}$ wielkością przeciętnego wynagrodzenia w gospodarce narodowej ${ }^{4} \mathrm{i}$ powiększa wartość dochodu narodowego o $23 \%$, a [ibidem]. Biorąc pod uwagę fakt wycofywania się państwa z szeregu sfer życia można spodziewać się, iż szereg usług finansowanych przez państwo, w obliczu braku funduszy, zostanie przesuniętych do sfery prywatnej, gdzie albo ktoś kto takich usług potrzebuje zapłaci niemałe pieniądze albo będzie musiał ów brak nadrobić domowymi sposobami. Nazywając rzecz po imieniu - zwiększy zakres i tak niemałych obowiązków przypisanych w Polsce kobietom. Chodzi tutaj np. o opiekę nad chorymi (przedwcześnie zwalnianymi ze szpitali ze względu na oszczędności szpitali), osobami w podeszłym wieku (ze względu na ograniczone możliwości dofinansowywania pobytów w domach opieki społecznej), dziećmi (które nie dostały się do nielicznych przedszkoli, albo nie radzą sobie samodzielnie $\mathrm{w}$ szkole pozbawionej dodatkowych zajęć wyrównawczych ze względu na brak funduszy) itd. Transformacja w Polsce odbywa poprzez eksternalizację kosztów jakie musi ponieść wolny rynek i obarczenie nimi nieodpłatnych pracowników - czyli kobiety. W wielu krajach Unii Europejskiej, dażenie do spetnienia kryteriów do przyjęcia europejskiej waluty działa na zasadzie programu strukturalnego dostosowania. W celu pomniejszania dziur budżetowych, rzqdy poszczególnych państw w coraz to większym stopniu zmniejszajq wydatki na opieke nad seniorami, bezrobotnymi, opieke zdrowotnq, opieke nad dziećmi; stabilność ekonomiczna jest osiagana $w$ zamian za rezygnację z bezpieczeństwa socjalnego [Wichterich: 2000: 106]. „Kurczenie się państwa" w Polsce, będące bezpośrednią przyczyną naszego wejścia w orbitę oddziaływania globalnych procesów gospodarczych (dostosowywanie się do wymogów Unii Europejskiej), polega m. in. na zmniejszaniu dotacji państwowych w wielu dziedzinach, a to z kolei bezpośrednio przekłada się na zwiększenie zakresu „niezagospodarowanych” obowiązków które ktoś musi wykonać.

Oczywiście można wysunąć tutaj argument, iż poprzez skoncentrowanie się na dążeniach do osiaggnięcia jak największego wzrostu gospodarczego sytuacja kobiet w Polsce, prędzej czy później, poprawi się. Sposób myślenia byłby tutaj następujący: jeśli poprawi się sytuacja ekonomiczna społeczeństwa jako całości także kobiety skorzystają na tej zmianie. Niestety, jak wykazali Inglehart i Morris [2000: 17], sam wzrost gospodarczy wcale nie musi automatycznie prowa-

\footnotetext{
${ }^{4}$ Powstaje pytanie jak oszacować wartość tej pracy? Otóż wystarczy obliczyć średni czas przeznaczony na wykonywanie poszczególnych czynności domowych a potem wycenić je według stawek godzinowych zawodów, którym odpowiadają poszczególne czynności. W Polsce tzw. kobieta niepracująca to: opiekunka w żłobku, przedszkolanka, nauczycielka, pielęgniarka środowiskowa, kucharka, cukiernik, sprzątaczka, rzeźnik, pracownik przetwórni owocowo-warzywnej, dziewiarka, magazynier, księgowa, stolarz, hydraulik, malarz, elektryk itd.
} 
dzić do poprawy sytuacji kobiet. Do osiagnnięcia równości płci niezbędne są trzy czynniki występujące równocześnie: wzrost gospodarczy, reformy prawno-instytucjonalne oraz zmiana kulturowa rozumiana m. in. jako zmiana świadomości kobiet na temat nich samych. Szeroko rozumiana zmiana kulturowa dotyczy nie tylko życia publicznego, ale przede wszystkim prywatnego - ludzie zaczynają przywiązywać coraz większą wagę do jakości życia rozumianej jako zwiększający się zakres autonomii jednostek, swobodnej ekspresji i rozmaitych możliwości osiagania wysokiego statusu społecznego - w przypadku kobiet nie tylko tradycyjnymi kanałami poprzez małżeństwo i posiadanie dzieci. Proces globalizacji przyśpiesza uznawanie praw kobiet i postęp $w$ demokratyzacji. Jednak na krótkq metę przeobrażenia wartości zwiększaja różnice kulturowe między społeczeństwami postindustrialnymi i agrarnymi, co za tym idzie, zwiększaja się też różnice pomiędzy kobietami żyjacymi $w$ tych społeczeństwach [Inglehart, Norris: 2003: 29].

Jedną z branż przemysłu w którym mamy do czynienia z feminizacją najemnej siły roboczej, niskimi płacami (najgorzej opłacany sektor polskiej gospodarki) oraz łamaniem międzynarodowych standardów pracy jest przemysł odzieżowy. Przemysł odzieżowy został w dużej mierze sprywatyzowany i nie jest obecnie objęty branżowym układem zbiorowym. Na polskim rynku funkcjonuje 44 tys. producentów odzieży, ale jedynie 1000 spośród polskich firm zatrudnia więcej niż 50 osób. Szacuje się, że około 70-80\% produkcji polskiego przemysłu odzieżowego zajmuje się tzw. „przeszyciem uszlachetniającym”, czyli szyciem odzieży dla zagranicznych marek (produkt finalny sygnowany jest obca metka). Odzież produkowana w Polsce jest eksportowana przede wszystkim do Niemiec, co czyni z Polski jednego z głównych dostawców odzieży na rynek niemiecki obok Chin, Turcji, Rumunii i Włoch. Producenci odzieży działajacy w Polsce dziela się na dwie grupy. W pierwszej znajduja się polskie marki (chociaż ich marki brzmiq obco), takie jak: Reserved, Top Secret, Tatuum, Atlantic czy Troll. Funkcjonuja one zgodnie z globalnymi trendami panujacymi $w$ przemyśle odzieżowym na świecie, rozlokowujac swoje fabryki w Chinach, Pakistanie, Bangladeszu, Turcji, co pozwala na obnizenie kosztów produkcji poprzez korzystanie z tańszej sity roboczej $i$ omijanie przestrzegania europejskich standardów pracy. W drugiej znajduja się obce marki. Polska jest dogodnym miejscem dla zachodnich koncernów, które tu lokujq swoje zakłady, czyniquc Polske jednym z największych eksporterów odzieży na rynku Unii Europejskiej. Mieszczace się w Polsce fabryki produkuja odzież dla znanych marek. Większość tej produkcji wytwarzana jest $w$ matych fabrykach, gdzie standardy pracy nie sq przestrzegane. Nagminnie pojawia sie wyzysk w postaci nieodpłatnej pracy w nadgodzinach, nie ma zapewnionej żadnej ochrony socjalnej, czy gwarancji stałego zatrudnienia, płace szwaczek wynoszq od 900 do 1300 zt (z nadgodzinami) [Szabuńko, Seifert, Kamińska: 2005: 11]. 
W Polsce zasługi w raportowaniu istniejących nieprawidłowości mają nie tylko Państwowa Inspekcja Pracy, ale również polskie i międzynarodowe organizacje pozarządowe zajmujące się m. in. monitorowaniem warunków pracy w zakładach pracy czy prowadzeniem kampanii edukacyjnych wśród polskich konsumentów. Do takich organizacji można zliczyć np. Polską Akcję Humanitarną $^{5}$, Clean Clothes Campaign ${ }^{6}$ - Polska, czy Koalicję Karat ${ }^{7}$, Fair Wear Foundation. Działalność wszystkich wymienionych organizacji pozarządowych przyczynia się do powolnej zmiany kulturowej zwiększającej zakres autonomii i poprawy jakości życia kobiet.

Kolejnym przykładem wpisywania się Polek w globalne trendy jest emigracja zarobkowa. Oficjalne dane podają na ogół liczbę około 3 milionów osób które w okresie transformacji wyjechało z Polski w poszukiwaniu pracy. Wśród wyjeżdzajacych jest duży procent kobiet powyżej 35 lat, dla których nie ma pracy $w$ kraju. Pracuja one za granica jako sprzataczki, opiekunki do dzieci lub osób starszych czy gosposie. Sa to często kobiety, które już urodzity i wychowaty dzieci, a następnie wyjechaty do pracy za granice, aby je utrzymać $i$ wyksztatcić. Ten typ kobiety emigrantki rzadko jest przedmiotem publicznego dyskursu, gdyż praca $w$ domach prywatnych, zazwyczaj nieformalna, czyni je niewidocznymi dla oficjalnych statystyk [Święćkowska: 2007: 1-2].

Emigracja zarobkowa Polek wpisuje się w globalne trendy w dwojakim sensie. Po pierwsze, w krajach Unii Europejskiej powstał atrakcyjny rynek prac domowych i opiekuńczych związany $\mathrm{m}$. in. z chęcią utrzymywania pewnego stylu życia przez tamtejsze klasy średnie (konieczność godzenia pracy zawodowej z prowadzeniem domu i opieką nad dziećmi) oraz ze starzeniem się wielu europejskich społeczeństw (Europejski Związek Emerytów szacuje liczbę starszych osób żyjących w Europie i potrzebujących opieki na około 50 milionów). W tym sensie kobiety emigrantki podejmujące niskopłatna pracę stanowią integralną część gospodarek krajów do których się udają. Migracje zarobkowe kobiet sq jednym z integralnych aspektów funkcjonowania wspótczesnej globalizacji. Tania praca kobiet, które przemierzaja granice, aby obstugiwać obszar spotecznej reprodukcji $w$ krajach bogatszych jest ważnym, lecz rzadko dostrzega$n y m$ w ekonomicznych rachunkach wkładem do światowej gospodarki [Święćkowska: 2007: 31]. Jak dotąd próby legalizowania ww. zajęć w krajach takich jak Niemcy, Holandia, a ostatnio także Polska, nie powiodły się z prostego powodu - oznaczałoby to podniesienie kosztów pracy, które musiałyby ponosić

\footnotetext{
${ }^{5}$ Najbardziej spektakularna akcją był projekt „Modnie i etycznie” zakończony przez PAH w grudniu 2009 r., więcej informacji dostępnych na stronie http://modnieietycznie.pl/.

${ }^{6}$ Przykładem może być raport z 2005 r. autorstwa Joanny Szabuńko, Anity Seifert i Anny Kamińskiej Warunki pracy kobiet w polskim przemyśle odzieżowym przygotowany przez CCC wspólnie z koalicją Karat.

${ }^{7}$ Chodzi przede wszystkim o Raport Karoliny Oponowicz i Agnieszki Chmieleckiej Sytuacja pracownic super $i$ hipermarketów z $2008 \mathrm{r}$. Więcej na ten temat na stronie: http://www.kobiety praca.org/.
} 
gospodarstwa domowe zatrudniające emigrantki. Po drugie, niejako „w miejsce kobiet które wyjechały z Polski" przyjeżdżają kobiety zza wschodniej granicy podejmując pracę w szarej i czarnej strefie. Czasem dochodzi wręcz do paradoksalnych sytuacji kiedy Polka wyjeżdżająca do jakiegoś kraju Europy zachodniej w celu opiekowania się czyimiś dziećmi, własne dzieci zostawia pod opieka wynajętej opiekunki ze Wschodu. Jak wykazują badania historyczne, rynek prac domowych (sprzątaczki, gosposie) zwiększa się wraz ze wzrastającym rozwarstwieniem społecznym w sferze dochodów [Moya: 2007].

Można oczywiście postawić pytanie na ile możliwości jakie niesie ze soba emigracja zarobkowa są dla kobiet korzystne. Podobnie jak i w innych regionach świata pozytywne jest zdobywanie pewnego zakresu finansowej niezależności. $\mathrm{O}$ wiele istotniejsze mogą być także inne doświadczenia jak nauka funkcjonowania w innej kulturze (w parze z nauką języka - o ile takowa ma miejsce), poszerzenie własnych horyzontów; podniesienie własnego statusu już po powrocie do rodzinnego kraju. $\mathrm{Z}$ drugiej jednak strony formy emigracji kobiet o których tutaj mowa niejako utwierdzają tradycyjne wzorce kobiecości realizującej się w wykonywaniu prac domowych i opiekuńczych. Po stronie kosztów niewątpliwie należy zaliczyć psychologiczne koszty rozłąki z rodziną, czy ewentualne trudne emocjonalnie doświadczenia związane $\mathrm{z}$ ryzykiem podejmowania pracy w szarej bądź czarnej strefie.

\section{Podsumowanie}

Analiza sytuacji kobiet w Polsce ukazuje podwójną twarz globalizacji. $\mathrm{Z}$ jednej strony wejście Polski w orbitę globalnych procesów gospodarczych przypieczętowana akcesją do Unii Europejskiej otwiera szereg możliwości. Sa to: transfer nowych technologii umożliwiający chociażby rozwój trzeciego sektora działającego po części na rzecz respektowania i egzekwowania praw kobiet, transfer wzorów i standardów z Zachodu w ramach których prawa kobiet pojmowane są jako integralna część praw człowieka, rozprzestrzenianie się wiedzy na temat międzynarodowych konwencji dotyczących standardów pracy, możliwości legalnego zatrudnienia za granicą itd. Należy jednak pamiętać, że akcesja nie gwarantuje zrównoważonego rozwoju. Przemiany jakie miały miejsce w Polsce w ciagu ostatnich dwudziestu lat odbyły się w ogromnej mierze kosztem kobiet poprzez składanie na ich barki szeregu opiekuńczych zadań, przy równoczesnym wykluczaniu ich ze sfery publicznej. Nowy podział pracy w obrębie europejskiego rynku pracy polega m. in. na uzupełnianiu braków kadrowych na niskopłatną siłę roboczą poprzez sięganie do rezerw jaką stanowią, obok innych nacji, bezrobotne Polki. Co więcej, w Polsce możemy zaobserwować postępującą feminizację proletariatu. Doskonałym przykładem jest tutaj przemysł odzieżowy. 


\section{Bibliografia:}

Dickensom Donna, 1997, Counting women in: globlization, democratization and the women's movement, [w:] A. McGrew (red.), The transformation of democracy? Globalization and territorial democracy, Polity Press, Cambridge UK, Malden USA.

Frobel Folker, Heinrichs Jurgen, Kreye Otto, 2000, The New International Division of Labour in the Word Economy, [w:] T. Roberts i A. Hite (red.), From modernization to globalization. Perspectives on development and social change, Blackwell, Malden USA, Oxford UK.

Graff Agnieszka, 2001, Świat bez kobiet. Płeć w polskim życiu publicznym, Wydawnictwo W.A.B., Warszawa.

Graff Agnieszka, 2008, Rykoszetem. Rzecz o ptci, seksualności i narodzie, Wydawnictwo W.A.B., Warszawa.

Inglehart Ronald, Norris Pippa, 2009, Wzbierajaca fala. Równouprawnienie płci a zmiana kulturowa $w$ świecie, PIW, Warszawa.

Kozłowski Michał, 2009, Aborcja, [w:] Kobiety i transformacja, „Bez dogmatu", nr 80.

Moya Jose C., 2007, Domestic Sernice in a Globar Perspective: Gender, Migration and Ethnic Niches, ,Journal of Ethnic and Migration Studies”, Vol. 33, no. 4.

Samouiller Segolene, Jabre Kareen, 2007, Prawa wyborcze i uczestnictwo kobiet w życiu politycznym, [w:] Ch. Ockrent (red.), Czarna księga kobiet, Wydawnictwo W.A.B., Warszawa.

Sassem Saskia, 2000, Cities in a world economy, PINE FORGE PRESS, Thousand Oaks, London, New Delhi.

Sassem Saskia, 2007, Globalizacja. Eseje o nowej mobilności ludzi i pieniędzy, Wydawnictwo Uniwersytetu Jagiellońskiego, Kraków.

Szacka Barbara, 2003, Wprowadzenie do socjologii, Oficyna Naukowa, Warszawa.

Titkow Anna, Duch-Krzystoszek Danuta, Budzowska Bogusława, 2002, Nieodpłatna praca kobiet, mity, realia i perspektywy, IFiS PAN, Warszawa.

Ward B. Kataryn, Pyle Jean Larson, 2000, Gender, Industrialization, Transnational Corporation and development: An Overview of Trends and Patterns, [w:] T. Roberts i A. Hite (red.), From modernization to globalization. Perspectives on development and social change, Blackwell, Malden USA, Oxford UK.

Wichterich Christa, 2000, The Globalized Woman: Reports from a Future of Inequality, Zed Books, London New York.

World Bank, 1996, From Plan to Market. World Development Report, New York. 


\title{
Źródła internetowe
}

Beneria Lourdes, 1999, Globalizacja, płeć i cztowiek z Davos, „Feminist Economics", nr 5:3, www.ekologiasztuka.pl/think.tank.feministyczny.

Desperak Iza, 2004, Kobiety i praca. Wielkie przegrane polskiej transformacji, www.ekologiasztuka.pl/think.tnk.feministyczny.

Human Development Report 1995, http://hdr.undp.org/en/reports/global/hdr1995/. Human Development Report 1999, http://hdr.undp.org/en/reports/global/hdr1999/. ILO 2002.

Kobiety i transformacja: krótki stownik, 2009, „Bez Dogmatu”, nr 80, http://www.iwkip.org/bezdogmatu/.

Nowicka Wanda, 2009, The struggle for Abortion Rights in Poland, [w.] R. Parker, R. Petchesky i R. Sember (red.), SexPolitics. Reports from the Front Lines, Sexuality Policy Watch, Ford Foundation, http://www.sxpolitics.org/frontlines/book/pdf/sexpolitics.pdf.

Oponowicz Karolina, Chmielecka Agnieszka, 2008, Kobiety o pracy w supermarketach, Raport z badania „Sytuacja pracownic super i hipermarketów”, Koalicja Karat, Warszawa, www.kobietpraca.org.

Szabuńko Joanna, Seifert Anita, Kamińska Anna, 2005, Warunki pracy kobiet w polskim przemyśle odzieżowym. Wyniki badań, KARAT Coalition, Warszawa, www.kobietpraca.org.

Święćkowska Teresa, 2007, Emigrantki $n$ globalnym rynku taniej pracy. Raport Think Tanku Feministycznego 2007/02, www.ekologiasztuka.pl/think. tank.feministyczny.

\section{ETHICAL DILEMMAS OF WOMEN'S WORK IN THE GLOBALIZATION ERA - POLISH CASE}

\begin{abstract}
Summary
Twenty years after the transformation in Poland is a good moment to try to answer the question of to what extent the global developmental trends influence the living conditions of Polish women in contemporary Poland. The main goal of this article is to present selected ethical dilemmas connected with women's paid and unpaid work in contemporary phase of globalization. In the article I focus on three major issues: 1) a selective character of globalization in Poland, in a sense that not everybody may be called a winner of neoliberal transformation; 2) the delocalization of production in which Polish women from working classes take actively part; 3 ) the new division of labour materializing itself, for instance in the feminization of cheap labour force (the feminization of proletariat), intertwined with feminization of poverty and the growing discrepancy in salaries.
\end{abstract}

Key words: globalization, gender and development, delocalization of production, feminization of proletariat, feminization of poverty. 